\title{
The Dietary Pattern, Nutritional Status, and Dual Burden of Malnutrition
}

\section{Kiran Yadav}

\begin{abstract}
India is currently witnessing the dual burden of malnutrition. The growing risk of overweight and obesity among Indians, accompanied by high undernutrition, is a big cause of worry. This paper is trying to focus on the trends and patterns of dual burden in India and how this dual burden is associated with diet and nutrition patterns. This paper tries to analyse the changes in dietary pattern from 2004-05 to 2015-16 and how it changes across the region and gender in India. We also discuss its association with the dual burden. Along with the consumption expenditure pattern, we also consider here the role of the level of physical activity in malnutrition. The paper also confers about the Public Distribution System that launched to address malnutrition in India and its challenges.
\end{abstract}

Keywords: Obesity, Malnutrition, Undernourished, Diet, Nutrition, Energy, Food groups

\section{Introduction}

Because of economic growth, rapid urbanisation, changing lifestyle, India is facing the dual burden of malnutrition. As the global burden of malnutrition is shifted to overnutrition, India faces a large proportion of undernourished people and a growing risk of overweight or obesity which further increases the risk of Non-Communicable Diseases (NCDs). As per a UN report on food safety and nutrition in world 2020, $14 \%$ of the population i.e. 189.2 million Indian is undernourished in 2017-19 whereas the prevalence of obesity is found in $3.9 \%$ of the population (34.3 million people) in 2016 and has been continuously increasing (The state of food security and nutrition in the world 2020, 2021) (UNICEF, 2020). Hence India is following the path of developing countries where obesity steadily becomes more prevalent but with a more 
unnourished population. The Global Hunger Index (GHI) 2020 report places India at 94 positions out of 107 countries with a $27.2 \mathrm{GHI}$ score, which shows that the hunger level in India is serious. As per the report, stunting in children under the age of 5 years is $34.7 \%$ and wasting in children under 5 is $17.3 \%$ and under-5 mortality is $3.7 \%$ in 2020 (GHI, 2020). Though the prevalence of undernourished, stunting and under-five mortality rate decreased over the past two decades in India, the rising prevalence of wasting in children under five years is a matter of concern. It also confirms this from the National Family and Health Survey NFHS round 4 data. This study is particularly focusing on NFHS round 4 data, as NFHS 5 complete data is yet to be published.

\section{Dual burden of malnutrition in India}

The dual burden of malnutrition i.e. undernutrition and obesity is a major concern for India. It associates overweight or obesity with many Non-Communicable Diseases (NCDs) such as hypertension, diabetes, cancers, cardiovascular diseases, and chronic respiratory diseases. Undernutrition leads to a reduction in work capacity and productivity, reducing earning capacity which leads to a vicious circle of poverty and ends up in hunger and mortality.

As per National Family and Health Survey (NFHS)-4 report, the comparison of malnutrition status between gender and region shows three patterns (a) the prevalence of both undernourishment and overweight or obesity is found to be higher in women as compared to men, (b) while undernourishment has declined in a decade, but overweight or obese has increased, (c) undernourishment is higher in rural areas, whereas, obesity is found to be higher in urban areas. This suggests that urbanisation is associated with a higher incidence of obesity.

Table1: Area-wise Nutritional status of Men and Women

\begin{tabular}{|l|l|l|l|l|l|l|}
\hline & \multicolumn{5}{|l|}{ 2015-16 } & \multicolumn{2}{l|}{ 2005-06 } \\
\hline Nutritional & Total & Urban & Rural & Total (\%) & Urban & Rural \\
Status & $(\%)$ & $(\%)$ & $(\%)$ & & $(\%)$ & $(\%)$ \\
\hline
\end{tabular}




\begin{tabular}{|l|l|l|l|l|l|l|}
\hline $\begin{array}{l}\text { Undernutrition } \\
\text { in women }\end{array}$ & 22.9 & 15.5 & 26.7 & 35.5 & 25 & 40.6 \\
\hline $\begin{array}{l}\text { Undernutrition } \\
\text { in men }\end{array}$ & 20.2 & 15.4 & 23 & 34.2 & 26.5 & 38.4 \\
\hline $\begin{array}{l}\text { Overweight or } \\
\text { obesity in } \\
\text { women }\end{array}$ & 20.6 & 31.3 & 15 & 12.6 & 23.5 & 7.4 \\
\hline $\begin{array}{l}\text { Overweight or } \\
\text { obesity in men }\end{array}$ & 18.9 & 26.6 & 14.3 & 9.3 & 15.9 & 5.6 \\
\hline
\end{tabular}

Source: NFHS round 4

The report of ICMR-National Institute of Nutrition (NIN) 2020, also confirms that the prevalence of overweight or obesity is higher among the urban population than the rural population. The chronic energy deficiency was higher in rural areas, as it was $35.4 \%$ in rural India as compared to $9.3 \%$ in urban. As per the NIN, low nutritious consumption is the reason behind it as only $5 \%$ of people in rural and $18 \%$ of people in urban areas consumed recommended food groups as an excellent source of protein.

In state-wise, as shown in Figure $1 \& 2$ below, the high proportion of undernourishment is found to be in east and central states such as Jharkhand (32\%) and Bihar (31\%) in case of women; Madhya Pradesh (28\%), and Uttar Pradesh and Bihar with 26\% each in case of men. While the high proportion of overweight or obesity is found to be in southern, northern and western states, with outlier Goa (34\%) in women's cases and Sikkim (35\%) in men's cases. Though in northeastern states, the prevalence of malnutrition is lower than in other regions, the prevalence of overweight or obesity is higher than undernutrition. This is also confirmed by the NIN report as shown in figure 4 where it is found that the prevalence of malnutrition is higher in North, South, and West regions whereas it is lowest in Northeast regions.

Overweight \& obesity and undernutrition may coexist at the same time because of an excess of certain diet consumption accompanied by poor and lack of nutritious diet. To see how malnutrition drives in India and its variation, it is necessary to understand the food consumption pattern and dietary trend in different regions and states of India. 


\section{Dietary Patterns in India}

The NFHS gives the data of consumption frequency of food items (pulses or beans, dark green vegetables, fruits, eggs, fish, chicken or meat, milk or curd) as never, daily, weekly, and occasionally by men (aged 15-54) and women (aged 15-49). The regular consumption in this paper is interchangeable with daily or weekly consumption.

As shown in table 2 in the appendix, the regular consumption of milk or curd and fruits is found to be higher in men than in women, whereas regular consumption of pulses or beans and fried foods is equal in men and women, however, men who never consumed fried food $(7.5 \%)$ is higher than compared to women $(4.7 \%)$. Those who never or occasionally consume pulses or beans and vegetables were found to be higher in women ( $10.1 \%$ and $14.5 \%$ respectively) than in men (9.4\% and $11.9 \%$ respectively). Almost half of the men and women (nearly 46\%) consume a vegetarian diet (milk or curd, pulses or beans, and vegetables) daily, however, fruits are less popular in a vegetarian diet as half of both men (48\%) and women (52\%) consume it occasionally. Men are found to be more regular in consuming non-vegetarian food including eggs, chicken or meat, and fish as compared to women. It is also noticed that the urban population consumes milk or curd more than the rural population. The regular consumption of pulses or beans and vegetables found to be slightly higher in the urban region than in the rural region. However, fruit consumption is highly deficient in a rural region with $43 \%$ among men and nearly $37 \%$ among women. The non-vegetarian food items also consumed higher in the urban region than in the rural region.

\section{Trends in diets pattern over a decade}

The regular consumption of milk or curd is increased over a decade in rural and urban areas for both genders as shown in table 3 in the appendix. In vegetarian food items, the regular consumption of pulses or beans by women is found to be almost stagnant in both region (at nearly $92 \%$ in urban and $89 \%$ in rural) whereas the regular consumption of vegetables among women is decreased in both rural (from $92 \%$ to $85 \%$ ) and urban areas (from $94 \%$ to $87 \%$ ). 
Among men, the regular consumption of pulses or beans found to be decreased in urban areas (from $93 \%$ to $91 \%$ ) but slightly increased in rural areas (from $89 \%$ to $90 \%$ ). A similar pattern has been found with men's regular consumption of fruits however, the vegetables' regular consumption has decreased in both urban (from 95\% to nearly 89\%) and rural regions (from approximately $93 \%$ to $88 \%$ ). The consumption of non-vegetarian food at least once a week has increased across all sections.

All these trends and patterns show that milk or curd regular consumption is increased across all sections, however, urban consumption is higher than rural. The regular consumption of pulses or beans more or less remains the same, but the regular consumption of vegetables decreased across all the sections. In urban areas, the men's consumption pattern follows a distinct pattern with pulses or beans and fruits as the regular consumption of both food items has decreased. It is also important to note that fruit consumption is very less among both men and women across the region. However, the consumption of non-vegetarian food items has increased in both regions for both genders (though urban consumption is higher than rural), it is also found that fish has the least consumption with eggs has highest in non-vegetarian food.

As per the MOSPI report, among three macronutrients, only fat shows an increasing trend, from $35.5 \mathrm{~g}$ per capita per day fat consumption in 2004-05, it increased to $41.6 \mathrm{~g}$ in rural areas whereas, in urban areas, it increases from $47.5 \mathrm{~g}$ to $52.5 \mathrm{~g}$. The fat intake for both rural and urban areas is far higher than the required norm of $28 \mathrm{~g}$ for rural and $26 \mathrm{~g}$ per capita per day in urban areas which explains the rising trend of obesity in India (MOSPI \& WFP, 2019). To get a more clear picture of patterns of macronutrients consumption, it is necessary to look at region-wise food and macronutrient data.

\section{The region-wise pattern of diet and nutrition}

\section{Calorie}

The NIN report 2020 is used to analyse the diet and nutrition pattern across regions however, it doesn't include north and northeast regions for rural areas. The recommended diet for 2000 calories per day as per the ICMR, is calorie/energy from cereals and millets should not be over 
$45 \%, 17 \%$ energy from pulses, eggs and flesh foods, $10 \%$ energy from milk and milk products, $8-10 \%$ from fruits and vegetables, $8 \%$ from nuts and seeds and $12 \%$ from fats and oil. The total fat intake should be less than or equal to $30 \%$ of energy. In urban areas, the average intake of total calories in the north $(1723 \mathrm{Kcal})$, central region $(1825 \mathrm{Kcal})$, west $(1738 \mathrm{Kcal})$ is lower than pool average Indian intakes while in the east (2013 Kcal), it is very close to average Indian intakes. The total calorie intake in the northeast (2908 Kcal) and south (2005 Kcal) is higher than the pooled average Indian intake in urban areas. In rural areas, the total calorie intake in the east (1983 Kcal) is lesser than the pooled average Indian intake while it is greater in the west $(2016 \mathrm{Kcal})$.

The food group's contribution to macronutrients region-wise is shown in figure4 below. As per the figure, the cereals and millets consumption is higher than the recommended dietary intake in all regions except north, where it is $40.7 \%$ of total calorie. The pulses, eggs and flesh food intake are lower than RDA in all regions, but it is lowest in central (7.8\%), northern (8\%) and western regions $(9.2 \%)$. The contribution of fat and oil in energy is higher than RDA in all regions except the south $(10.3 \%)$. The fat and oil consumption is highest in the northern region (24\%) followed by the western region (18.6\%). Though the milk and milk products consumption is below RDA in all regions, it is lowest in eastern (2.8\%) and northeast (1.6\%). The fruits and vegetable consumption is lower than RDA in all regions, but it is lowest in the northeast (1.5\%) and highest in the west (3.\%). The energy from nuts and oilseeds is negligible in almost all regions, with only the exception of the southern with a $4 \%$ share. The same pattern is followed with rural areas with a difference is that the cereals contribute higher energy in rural areas than urban.

\section{Protein}

Being the staple food, cereals and millets contribute the highest share in protein intake in both rural and urban areas in all regions. Central India is at the top with total protein intake $(48.6 \mathrm{~g} / \mathrm{d})$ followed by Northeastern India (41.2 g/d). North India consumes the lowest protein intake with $21.8 \mathrm{~g} / \mathrm{d}$. In central India, cereals and millets' contribution to protein $(58.8 \%$ in urban; $57.3 \%$ in rural) was higher than the national average (47.5\% in urban; $48.4 \%$ in rural). But the flesh foods such as meat, poultry, fish and seafood contribution to protein is lowest in both rural and urban areas in central India though, it is higher in rural areas than urban areas. In the northern 
region, pulses \& legumes and milk products contribute a higher proportion to protein intake. Pulses \& legumes contribute the highest percentage of protein $(22 \%)$ in the urban area of northeast India, followed by flesh foods. While in the southern region, the flesh food $(17 \%$ in urban; $28 \%$ in rural) and milk \& milk products (7.7\% in urban; $6 \%$ in rural) contribute a higher percentage of protein. Notably, the cereals contribution to protein intake is lowest in south India among all regions in both areas. In the east and west region, protein from animal products (flesh foods + milk products) is higher in both areas but in urban areas, the protein from flesh food contribution is higher in east India whereas milk products contribute higher protein in west India.

\section{Carbohydrates}

The average intake of carbohydrates is $289 \mathrm{~g} /$ day in urban and $368 \mathrm{~g} / \mathrm{day}$ in rural areas. Cereals and millets among all food groups contribute the highest percentage of carbohydrates intake (73.4\% in urban and $80.2 \%$ in rural areas). Pulses \& legumes contribution to carbohydrate intake is only $6.5 \%$ in urban areas and $6.7 \%$ in rural areas, while roots \& tubers contribute $3.8 \%$ and $8.2 \%$ in urban and rural areas, respectively. Northeast India consumes the highest carbohydrates with 458g/day, followed by east India with $323 \mathrm{~g} / \mathrm{day}$. The contribution of cereals and millets to carbohydrates intake is almost the same among all regions in rural areas, but in urban areas, it is higher in the northeast region (78\%) followed by the eastern region (76.8\%) and lowest in the northern region (64.7\%). Pulses \& legumes contribution in carbohydrates is highest in the northeast (9.6\%) followed by northern region (7.7\%) and lowest in the eastern (5.6\%) and southern region (6.4\%) in urban areas while in rural areas its highest in the west $(8.3 \%)$ and lowest in the east $(5.5 \%)$. The eastern region has the highest share of roots \& tubers in carbohydrates in both areas (6.8\% urban; $14 \%$ rural) while the southern region has the lowest in both areas (2.3\% urban; $2.2 \%$ rural).

\section{Fat}

In urban areas, $25 \%$ of the individuals consume over 30 calorie/day from fat or oil, which is higher than the recommended level. However, around $84 \%$ of the rural and $38 \%$ of the urban population had less than $20 \%$ of energy/day from fat/oil, which is below the recommended level. The average intake of total fat is $51.6 \mathrm{~g} /$ day in urban and $36 \mathrm{~g} /$ day in rural India, out of 
which $15.22 \%$ in urban and $5.8 \%$ in rural areas comes from visible (added oil/fats). This clearly says that fat consumption is higher among urban households than rural households, and a major proportion of this fat is coming from edible oil and additional fat consumption. The visible fat consumption is highest in the north $(67.3 \%)$ and the northeastern region (61.5\%) and lowest in the eastern region (42.8\%). In urban areas, fat intake from visible fat is highest in north India $(68.2 \%)$ followed by the northeast region $(64.1 \%)$. In the south region, other food sources contribute (54\% to urban; $57.1 \%$ in rural) the highest fat intake as compared to visible fat (46\% in urban; $42.9 \%$ in rural). Meanwhile, in rural areas, in all regions except the east, the contribution of fat from food sources is higher than visible fat however, the gap between both sources is not so high.

In summary, in north India, the calorie consumption is majorly driven by the visible fat than pulses or flesh foods, whereas south India consumption is largely driven by flesh foods and in west India, milk and milk products, and visible fat play an important part. In the northeast region, pulses, legumes and flesh foods have largely driven the diet, while in east and central regions, cereals have driven the diet. The chief contribution of food which has a high proportion of fat reflects why overnutrition is higher in the north, south and western region. But why malnutrition is lower in the northeastern region and undernutrition is higher in the central and eastern region is still not answered.

To understand high undernutrition in the central and eastern region, cereals should be kept in concern. As cereals are a major staple food in India and drive the diet in these regions. As per NSS report no.555, Indian spend approximately $11 \%$ of Monthly Per Capita Expenditure (MPCE) on cereals \& cereals products consumption in rural areas and $6.7 \%$ in urban areas. The Public Distribution System has a very important role in providing cereals to the mass. Hence understanding the PDS, its leakages and challenges are pertinent.

\section{PDS system and leakages}

The National Food Security Act which is also called the Right to Food Act was passed in 2013, aimed to supply subsidised food grains to about $2 / 3$ rd of the population ( $75 \%$ of rural and $50 \%$ of urban population) under the Targeted Public Distribution System (PDS) to reduce 
malnutrition and poverty in India (Government of India, 2019). The beneficiaries under the TPDS were based on Below Poverty Line (BPL) and Above Poverty Line (APL). In 2011-12, 26.97 crore population were below the poverty line as per the Tendulkar method on Mixed Reference Period (MRP) (RBI, 2020). Whereas PDS covers 80 crore population to subsidise food, this says that affordability of food is not limited to the poor only. (Economic Survey, 2020). As per NSS report no.588, though the consumption of major staple food (rice and wheat) has been declining, the share of PDS purchase in per capita consumption of these staple foods has increased. With rice, the share of PDS is doubled in rural areas and increased by $66 \%$ in urban areas whereas, for wheat, it has more than doubled since 2004-05. This shows that people are largely consuming cereals through the PDS.

With rice, the PDS purchase contribution is relatively higher in southern states of Tamil Nadu (rural: 53\%, urban: 43\%), Karnataka (rural: 45\%, urban: 25\%), Chhattisgarh (rural: 38\%, urban: 30\%), Kerala (rural: 36\%, urban: 30\%) and Andhra Pradesh (rural: 33\%, urban: 22\%). Interestingly, West Bengal has the lowest share of PDS purchase of rice (rural: 10\%, urban: $6 \%$ ) even though rice is their staple food. Whereas for wheat, the highest contribution of PDS purchase is in Maharashtra (rural: 40\%, urban: 10\%), Madhya Pradesh (rural: 36\%, urban: 23\%), Gujarat (rural: 31\%, urban: 5.7\%) (NSS report no. 565). However, PDS is also gripped with many loopholes in implementation and identifying the target. Experts' studies show that $41 \%$ error of exclusion and around $37 \%$ error of beneficiaries inclusion is found in PDS, which means misclassification of the needy people. However, the exclusion error has declined during 2004-05 to 2011-12 though the inclusion error has increased both errors are high. (NITI Aayog, 2016)

The working paper number 294 of ICRIER claim that the existing PDS system benefits majorly the better-off states than states with high poor populations. The study finds that as we move to the states with a high proportion of poor, it also increases the share of total leakage. In 15 states, over 50\% PDS grain leakage as a proportion of off-take was found. As per the study, 5 states (UP, Bihar, MP, Maharashtra, and West Bengal) which make up around $60 \%$ of the poor population accounted for over $52 \%$ of total grain leakage. The leakage is measured by the difference between grains off-taken from the central agencies and grain consumption by PDS beneficiaries. This also shows that the states that come under the central and east region i.e. UP 
(15.32\%), MP (5.83\%), Bihar (9.61\%), Jharkhand (3.59\%), West Bengal (11.77\%), and Odisha $(3.47 \%)$ constitute around half of the total grain leakage. In that region, only Chhattisgarh has zero leakage because the paper did not look into the exclusion and inclusion error. Some states like Chhattisgarh, Tamil Nadu and Andhra Pradesh extended the coverage of beneficiaries which underestimated the grain supply hence, under-reporting of leakages (Gulati and Saini, 2015). However, Dreze and Khera (2015) found that it based the estimation by Gulati and Saini on many inaccuracies and mistakes. They find states like Chhattisgarh, Odisha, and Bihar saw a large dip in leakage because of PDS reform introduced in recent years in these states. While other states like MP, UP, and Maharashtra show no improvement in leakage.

The reforms in PDS include fresh ways of reducing leakage such as Chhattisgarh and Tamil Nadu tracks the PDS through GPS technology and SMS based monitoring system and many other states digitise the ration cards. However, the sustainability of the whole food distribution mechanism is also an enormous challenge, as it is expected that food procurement will increase steadily and lack of an adequate food storage system would be a cause for concern. Besides, the rising cost of procurement also puts the question on financial feasibility as the central government bears a large financial cost of food subsidy and the cost of procuring and delivering food is already six times the sale price. (Balani, S., 2013). Though alternatives of PDS such as direct cash transfers and food coupons are also discussed among policymakers, yet the importance of PDS is not deniable. Many studies batted for expanding coverage of beneficiaries under PDS and different educational programs to create more awareness about food choices to remove undernutrition.

The leakage and coverage of beneficiaries in PDS is a debatable topic. While we can argue over the proportion of leakage or reduction in it, but it is undeniable that in some states (UP, West Bengal, Maharashtra, MP) the leakage is high which restricts the large proportion of people to get the cereals at a subsidised rate. All these states fall into the east and central region except Maharashtra, however, there is no direct relationship established between undernutrition and leakage in PDS. With overnutrition, along with diet, physical activity also determines the health of people. 


\section{Physical Activity}

Along with an unhealthy diet, insufficient physical activity is also the major reason for the growing number of NCDs cases in India. The lack of adequate physical activity in individuals increases the risk of Non-communicable diseases such as cancer, heart disease, stroke, and diabetes by $20-30 \%$ and shorten the lifespan by 3-5 years. Last year a study by WHO on physical activity finds that over $80 \%$ of adolescents did not meet the recommended norm of physical activity globally. The study finds the lower level of insufficient physical activity in India (72\% of boys and $76 \%$ of girls were insufficiently active in 2016) along with Bangladesh may be because of a strong focus on cricket by boys and increased domestic chores in the home by girls (WHO, 2019). However, though India is below the global average in insufficient physical activity, still more than half of Indian adolescents are not meeting sufficient physical activity.

A study from (phase-1) ICMR-INDIAB on the physical activity of India finds that $54.4 \%$ of individuals were inactive, which translates to 392 million inactive individuals. Physical inactiveness was more common in urban areas (65\%) as compared to rural areas $(50 \%)$ which may attribute to a better facility. In the study, men were found to be more active than females besides almost $92 \%$ of the individual did no recreational activity. Even for those who performed some kind of recreational activity, the time spent in moderate to intense activity was less than $20 \mathrm{~min} /$ day (Anjana, et al., 2014). Though this study was conducted in four regions (south, east, west, and north), the study comprises only four states, one state from each region of India, and this is the largest study related to physical activity by ICMR in India. This suggests that more research needs to be done on physical activity in India, as there is no proper data available for physical activity on a large scale or state-wise. Hence, in this study, occupational activity from NFHS-4 round data is used as a proxy variable to measure physical activity.

NFHS captures the occupation of individuals and divides it into distinct groups such as professional/technical/managerial, clerical, sales, agricultural services, skilled and unskilled manual, not working. This group is further divided into high-intensity physical activity, lowintensity physical activity, and not working. The high-intensity activity comprises agricultural and skilled-unskilled manual and the rest is included in the low-intensity activity. The statewise series of high-intensity activity and overnutrition found a negative correlation with -0.43 
in men's case and -0.41 in women's case. The low-intensity activity found a positive correlation with overnutrition with 0.53 in men case and 0.37 in women's case. The correlation is lower in women. The physical activity status for men shows that in the east and central region, the highintensity physical activity is higher than the national average whereas, in the north and southern region, the low-intensity physical activity is relatively higher. In the northeast and west region, the proportion of high-intensity activity and low-intensity activity both are high. With females, the north, east, west, and south regions have lower levels of high-intensity activity than the national average. Though in eastern regions, the proportion of low-intensity activity is also lower than the national average. In the central region, the high-intensity activity is higher among females whereas, in the northeastern region, both the high-intensity and low-intensity activity level is higher than the national average. Though it is pertinent to note that a large proportion of women (almost over 2/3rd) are not working and there is no method to measure their physical activity level.

In summary, in the northeast region, people engage in both high- and low-intensity activity level, whereas in central India, individuals largely engage in high-intensity activity level. In the north and south India, individuals largely involve in the low-intensity activity. However, the physical activity level in Chandigarh, Delhi, Goa and Puducherry justify the high proportion of overweight in these UTs in both male and female. However, still, in many states, such as Sikkim, Andhra Pradesh, Andaman \& Nicobar Island, the high proportion of overweight in men does not reflect with the physical activity level there. In northeast India, both high and low-intensity physical activity level is unable to justify the low malnutrition level in the region. The gender of the family head, as shown by NFHS data, finds that the female family head is higher in Lakshadweep, Meghalaya, Himachal Pradesh, Daman \& Diu, and Goa, which to some extent reflect a high proportion of overnutrition.

\section{Conclusion}

NFHS data shows that malnutrition is higher in women and overweight or obesity has increased over the decade and is more prevalent in urban areas. The diet of men and women follows the same pattern except for pulses or beans and fruits. However, the diet rich in protein and fat was found to be higher in men than women which might be associated with high malnutrition in women than men. The diet high in dairy and non-vegetarian food items has increased over the 
decade besides fibre-rich diets such as fruits, vegetables and pulses have not significantly improved over a decade which increases the risk of overweight or obese people. However, the high consumption of dairy products and non-vegetarian foods in urban areas and highly deficient consumption of fruits in rural areas may somewhat explain the high prevalence of overweight or obesity in urban areas and undernutrition in rural areas.

Among all three macronutrients, only fat shows an increasing trend and also a sign of worry as the fat intake is higher than the required norm. Overall, the state-wise analysis shows that undernutrition was high in eastern and central states (with outliers Rajasthan and Gujarat) whereas the prevalence of overweight and obesity was high in southern, northern, and western states. In north India, the calorie consumption is majorly driven by the visible fat than pulses or flesh foods, whereas south India consumption is largely driven by flesh foods and in west India, milk and milk products, and visible fat play an important part. In the northeast region, pulses, legumes and flesh foods have largely driven the diet, while in east and central regions, cereals have driven the diet. The chief contribution of food which has a high proportion of fat reflects why overnutrition is higher in the north, south and western region. As cereals play a pivotal role in the diet, the purchase of cereals from PDS has increased however, a high error has been found in identifying the actual beneficiary people. Along with this, a high proportion of leakage is found in states belonging to east and central regions however, no direct relationship is clear between undernutrition and leakage. The individuals largely engage in high-intensity activity levels in the central region and low-intensity activity in the north and south India justify the overnutrition level, but physical activity level is unable to justify low malnutrition in the northeast region. 


\section{Reference:}

Anjana, R. M., Pradeepa, R., Das, A. K., Deepa, M., Bhansali, A., Joshi, S. R., et al, 2014, Physical activity and inactivity patterns in India - results from the ICMR-INDIAB study (Phase-1) [ICMR-INDIAB-5]. The international journal of behavioral nutrition and physical activity, 11(1), 26. https://doi.org/10.1186/1479-5868-11-26

Balani, S. 2013, Functioning of the Public Distribution System: An Analytical Report, PRS $\begin{array}{llll}\text { Legislative } & \text { Research, } & \text { Accessed }\end{array}$ https://www.prsindia.org/administrator/uploads/general/1388728622 TPDS\%20Thematic\% 20Note.pdf

Dreze, J. and Khera, R., (2015), Understanding leakages in the Public Distribution System, Economic \& Political Weekly, Vol L(7)

Economic Survey, 2019-20, Agriculture and Food Management, Accessed from https://www.indiabudget.gov.in/economicsurvey/doc/vol2chapter/echap07_vol2.pdf

Express Food \& Hospitality, 2019, NRAI India Food Services Report (IFSR) 2019: The sector is projected to grow at a CAGR of $9 \%$ by 2022-23, Accessed from https://www.foodhospitality.in/in-focus/nrai-india-food-services-report-ifsr-2019-the-sectoris-projected-to-grow-at-a-cagr-of-9-per-cent-by-2022-

23/417232/\#: :text=The\%20sector\%20is\%20estimated\%20at,food\%20service\%20sector\%20 in $\% 20$ India.\&text=The $\% 20$ organised $\% 20$ segment $\% 20$ comprises $\% 20$ standalone $\% 20$ and $\% 20$ chain\%20restaurants.

Food and Agriculture Organisation (FAO), India at a glance, Accessed from http://www.fao.org/india/fao-in-india/india-at-a-glance/en/

Global Hunger Index (GHI), 2020, “2020 Global Hunger Index by Severity”, Accessed from https://www.globalhungerindex.org/results.html

Gulati, Ashok; Saini, Shweta (2015): Leakages from Public Distribution System (PDS) and the way forward, Working Paper, No. 294, Indian Council for Research on International Economic Relations (ICRIER), New Delhi

ICMR-National Institute of Nutrition (NIN), 2020, What India Eats, Department of Health Research, Ministry of Health and Family Welfare (MoHFI), Government of India, Accessed from https://www.nin.res.in/nutrition2020/what_india_eats.pdf 
Keshari, P. \& Mishra, C.P., 2016, Growing menace of fast food consumption in India: time to act, International Journal of Community Medicine and Public Health, 3(6), 1355-1362, Accessed from https://www.ijcmph.com/index.php/ijcmph/article/view/394/382

Ministry of Statistics and Programme Implementation (MOSPI), Government of India, 2014, Nutritional Intake in India, 2011-12, NSS $68^{\text {th }}$ round, Report no. 560, Accessed from http://mospi.nic.in/sites/default/files/publication_reports/nss_report_560_19dec14.pdf

Ministry of Statistics and Programme Implementation (MOSPI), Government of India, 2014, Household Consumption of Various Goods and Service in India, 2011-12, NSS $68^{\text {th }}$ round, $\begin{array}{llll}\text { Report } & \text { no. } & \text { Accessed } & \text { from }\end{array}$ http://mospi.nic.in/sites/default/files/publication_reports/Report_no558_rou68_30june14.pdf

Ministry of Statistics and Programme Implementation (MOSPI), Government of India, 2015, Public Distribution System and Other Sources of Household Consumption, 2011-12, NSS $68^{\text {th }}$ $\begin{array}{lllll}\text { round, } & \text { Report } & \text { no. } & \text { Accessed }\end{array}$ http://mospi.nic.in/sites/default/files/publication_reports/report_565_26june2015.pdf

Ministry of Statistics and Programme Implementation (MOSPI), Government of India, 2014, Level and Pattern of Consumer Expenditure, 2011-12, NSS 68 ${ }^{\text {th }}$ round, Report no. 555

Ministry of Health and Family Welfare (MoHFW), Government of India, UNICEF and Population Council. 2019. Comprehensive National Nutrition Survey (CNNS) National Report. New Delhi.

Ministry of Statistics and Programme Implementation (MOSPI), Government of India and World Food Programme (WFP), Food and Nutrition Security Analysis, India, 2019, Accessed from http://mospi.nic.in/sites/default/files/publication reports/document\%281\%29.pdf

Ministry of Consumer Affairs, Food \& Public Distribution, Government of India, National Food Security Act, Department of Food \& Public Distribution, Accessed from https://dfpd.gov.in/nfsa-act.htm

NFHS, 2020, "National Family Health Survey, India", Accessed from http://rchiips.org/nfhs/index.shtml 
NITI Aayog, Government of India, 2016, Evaluation study on the role of the public distribution system in shaping household and nutritional security India, DMEO Report No.233, Accessed from https://niti.gov.in/writereaddata/files/document_publication/Final\%20PDS\%20Reportnew.pdf

Panda, B.K., Mohanty, S.K., Nayak, I., Shastri, V.D., and Subramanian, S.V., 2020, Malnutrition and Poverty in India: Does the use of public distribution system matter? BMC Nutrition, 6 Article no.41, Accessed from https://bmcnutr.biomedcentral.com/articles/10.1186/s40795-020-00369-0

Reserve Bank of India, Handbook of Statistics on the Indian Economy, 2019-20, Accessed from

https://rbidocs.rbi.org.in/rdocs/Publications/PDFs/0HBS202024D4CA0CC03F4674B040F7D EDE7E5360.PDF

Suryanaranya, M.H., \& Silva, D., 2007, Is targeting the poor a penalty on the food insecure? Poverty and Food Insecurity in India, Journal of Human Development, volume 8, 89-107, Accessed from https://www.tandfonline.com/doi/abs/10.1080/14649880601101457

UNICEF, 2020, "The state of food security and nutrition in the world 2020", Accessed from https://www.unicef.org/reports/state-of-food-security-and-nutrition-2020

Unicef.org. 2021. The state of food security and nutrition in the world 2020. [online] Available at: <https://www.unicef.org/reports/state-of-food-security-and-nutrition-2020> [Accessed 12 March 2021].

WHO, 2019, New WHO-led study says majority of adolescents worldwide are not sufficiently physically active, putting their current and future health at risk, Accessed from https://www.who.int/news/item/22-11-2019-new-who-led-study-says-majority-ofadolescents-worldwide-are-not-sufficiently-physically-active-putting-their-current-andfuture-health-at-risk 


\section{Appendix}

Table2: Frequency of food consumption by men and women in 2015-16 and 2005-06

\begin{tabular}{|c|c|c|c|c|}
\hline & \multicolumn{2}{|c|}{ Men } & \multicolumn{2}{|c|}{ Women } \\
\hline Consumption of food groups & 2015-16 (\%) & $2005-06(\%)$ & $\begin{array}{c}\text { 2015-16 } \\
(\%)\end{array}$ & $\begin{array}{c}\text { 2005-06 } \\
(\%)\end{array}$ \\
\hline \multicolumn{5}{|c|}{ Milk or curd } \\
\hline Never & 5 & 7 & 7.3 & 11.4 \\
\hline Daily & 46.2 & 46.7 & 45 & 39.8 \\
\hline Weekly & 28.8 & 20.5 & 22.9 & 15.6 \\
\hline Occasionally & 20 & 25.8 & 24.7 & 33.2 \\
\hline \multicolumn{5}{|c|}{ Pulses or Beans } \\
\hline Never & 0.4 & 0.9 & 0.6 & 0.9 \\
\hline Daily & 46.5 & 52.1 & 44.8 & 52.7 \\
\hline Weekly & 44.1 & 38.6 & 45.1 & 36.8 \\
\hline Occasionally & 9 & 8.4 & 9.5 & 9.6 \\
\hline \multicolumn{5}{|c|}{ Dark green leafy vegetables } \\
\hline Never & 0.5 & 0.4 & 0.4 & 0.3 \\
\hline Daily & 46.6 & 59.1 & 47.2 & 64.2 \\
\hline Weekly & 41.5 & 34.5 & 38.3 & 28.7 \\
\hline Occasionally & 11.4 & 6 & 14.1 & 6.8 \\
\hline \multicolumn{5}{|c|}{ Fruits } \\
\hline Never & 1.9 & 2.6 & 2.6 & 3.5 \\
\hline Daily & 10.9 & 13.1 & 12.4 & 12.7 \\
\hline Weekly & 39.6 & 34.4 & 33.2 & 27.2 \\
\hline Occasionally & 47.6 & 50 & 51.8 & 56.6 \\
\hline \multicolumn{5}{|c|}{ Eggs } \\
\hline Never & 19.6 & 23.3 & 29.3 & 34.8 \\
\hline Daily & 4.9 & 5.2 & 4 & 3.5 \\
\hline Weekly & 44.7 & 36.1 & 37.4 & 28.8 \\
\hline Occasionally & 30.7 & 35.3 & 29.4 & 32.9 \\
\hline
\end{tabular}




\begin{tabular}{|c|c|c|c|c|}
\hline \multicolumn{5}{|c|}{ Fish } \\
\hline Never & 27.3 & 30.5 & 35.1 & 37.5 \\
\hline Daily & 4.8 & 6.2 & 5.6 & 6.3 \\
\hline Weekly & 33.8 & 25.1 & 28.4 & 21.9 \\
\hline Occasionally & 34.2 & 38.2 & 30.9 & 34.3 \\
\hline \multicolumn{5}{|c|}{ Chicken or Meat } \\
\hline Never & 23 & 25.6 & 31.8 & 35.1 \\
\hline Daily & 1.8 & 1.2 & 1.1 & 0.9 \\
\hline Weekly & 38.9 & 27.1 & 31.5 & 21.8 \\
\hline Occasionally & 36.3 & 46 & 35.7 & 42.2 \\
\hline \multicolumn{5}{|c|}{ Fish or Chicken or Meat } \\
\hline Never & 21.6 & 23.9 & 29.9 & 32.6 \\
\hline Daily & 5.7 & 6.9 & 6.1 & 6.8 \\
\hline Weekly & 43.2 & 34.1 & 36.6 & 28.5 \\
\hline Occasionally & 29.5 & 35.1 & 27.3 & 32 \\
\hline \multicolumn{5}{|c|}{ Fried food } \\
\hline Never & 7.5 & & 4.7 & \\
\hline Daily & 9.8 & & 9.8 & \\
\hline Weekly & 35.6 & & 35.7 & \\
\hline Occasionally & 47.1 & & 49.7 & \\
\hline \multicolumn{5}{|c|}{ Aerated drinks } \\
\hline Never & 11.6 & & 16.5 & \\
\hline Daily & 6.5 & & 4.5 & \\
\hline Weekly & 25.6 & & 19.5 & \\
\hline Occasionally & 56.2 & & 59.5 & \\
\hline
\end{tabular}

Source: NFHS round 4 and NFHS round 3

Table3: Men and women's diet over the decade in rural and urban areas

2015-16 (\%)

2005-06 (\%) 


\begin{tabular}{|c|c|c|c|c|}
\hline $\begin{array}{l}\text { Daily or Weekly } \\
\text { Consumption }\end{array}$ & $\begin{array}{l}\text { Urban } \\
\text { Areas }\end{array}$ & $\begin{array}{l}\text { Rural } \\
\text { Areas }\end{array}$ & $\begin{array}{l}\text { Urban } \\
\text { Areas }\end{array}$ & $\begin{array}{l}\text { Rural } \\
\text { Areas }\end{array}$ \\
\hline Milk or Curd & 80.4 & 71.6 & 74.5 & 62.9 \\
\hline Pulses or Beans & 91.3 & 90.2 & 93 & 89.4 \\
\hline Vegetables & 88.5 & 87.9 & 95.4 & 92.5 \\
\hline Fruits & 62.6 & 43 & 63.2 & 38.3 \\
\hline Eggs & 53.8 & 47.1 & 48.7 & 37.1 \\
\hline Fish & 40.1 & 37.6 & 34.7 & 29.3 \\
\hline Chicken or Meat & 46 & 37.3 & 37.5 & 23.1 \\
\hline Fish or Chicken or Meat & 52.8 & 46.5 & 47.3 & 37.3 \\
\hline Fried Foods & 47.5 & 44 & & \\
\hline Aerated Drink & 38.7 & 28.1 & & \\
\hline
\end{tabular}

Source: NFHS round 4 and NFHS round 3

Figure1.1: State-wise Undernutrition and Overweight or Obesity in Men 


\section{Malnutrition in Men}

Undernutrition Overweight or Obesity

India

North

Chandigarh

Delhi

Haryana

Himachal Pradesh

Jammu \& Kashmir

Punjab

Rajasthan

Uttrakhand

Central

Chattisgarh

Madhya Pradesh

Uttar Pradesh

East

Bihar

Jharkhand

Odisha

West Bengal

Northeast

Arunachal Pradesh

Assam

Manipur

Meghalaya

Mizoram

Nagaland

Sikkim

Tripura

West

Dadra \& Nagar Haveli

Daman \& Diu

Goa

Gujarat

Maharashtra

South

Andaman \& Nicobar Island Andhra Pradesh

Karnataka

Kerala

Lakshadweep

Puducherry

Tamil Nadu

Telangana
20.2

18.9

\begin{tabular}{|c|c|c|c|}
\hline 21.7 & & & 32 \\
\hline 17.7 & & 24.6 & \\
\hline 11.3 & 20 & & \\
\hline 18 & & 22 & \\
\hline 11.5 & 20.5 & & \\
\hline 10.9 & 27.8 & & \\
\hline 22.7 & & & 13.2 \\
\hline 16.1 & & 17.7 & \\
\hline
\end{tabular}

\begin{tabular}{|l|c|}
\hline 24.2 & 10.2 \\
\hline 28.4 & 10.9 \\
\hline 25.9 & 12.5 \\
\hline & \\
\hline 25.5 & 12.6 \\
\hline 23.8 & 11.1 \\
\hline 19.5 & 17.3 \\
\hline 19.9 & 14.2 \\
\hline
\end{tabular}

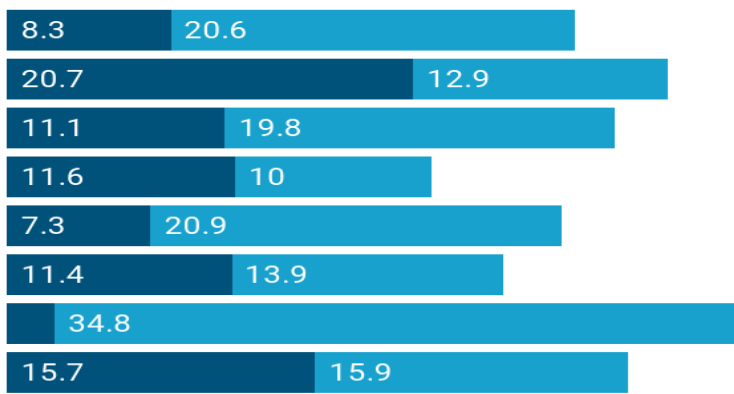

\begin{tabular}{|c|c|c|}
\hline 19.7 & & 22.9 \\
\hline 12 & 30.7 & \\
\hline 10.8 & 32.7 & \\
\hline 24.7 & & 19.7 \\
\hline 19.1 & & 23.8 \\
\hline
\end{tabular}

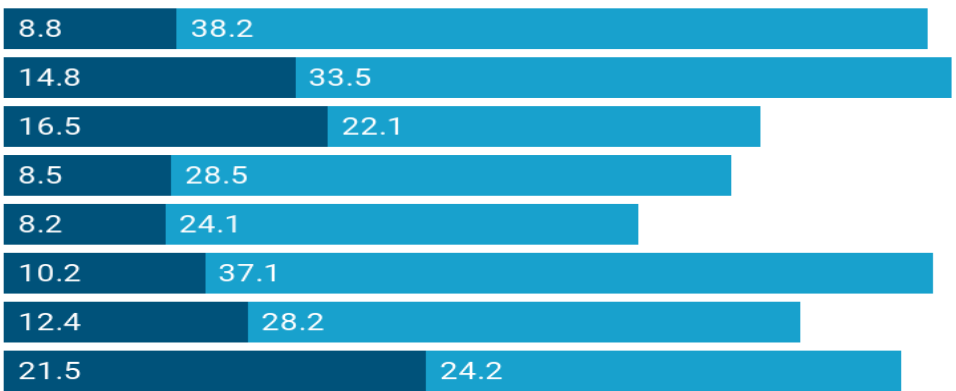


Figure1.2: State-wise Undernutrition and Overweight or Obesity in Women

\section{Malnutrition in Women}

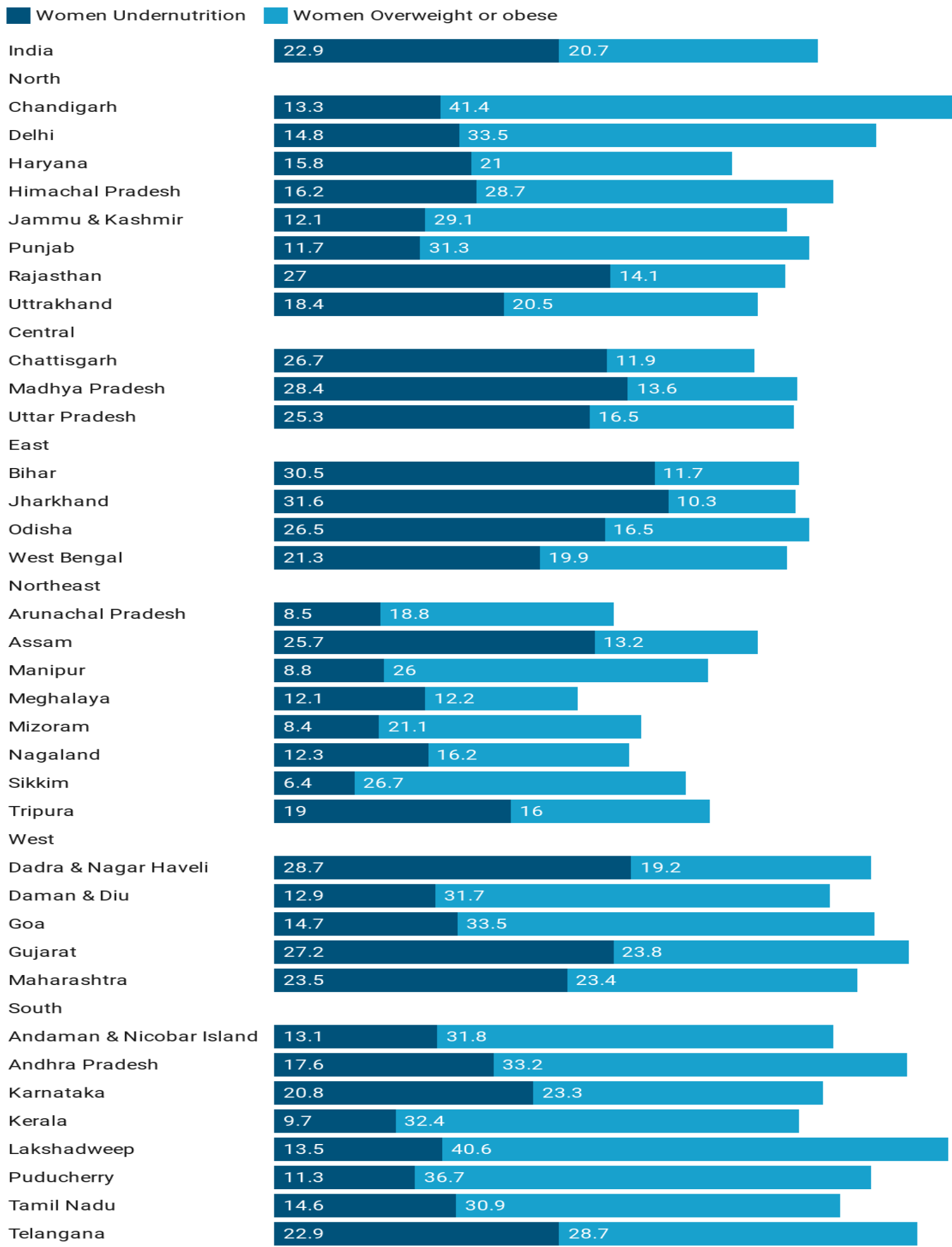

Source: NFHS-4 - Created with Datawrapper

Figure 2.1: Nutritional status region-wise - Urban 
Sanrachana

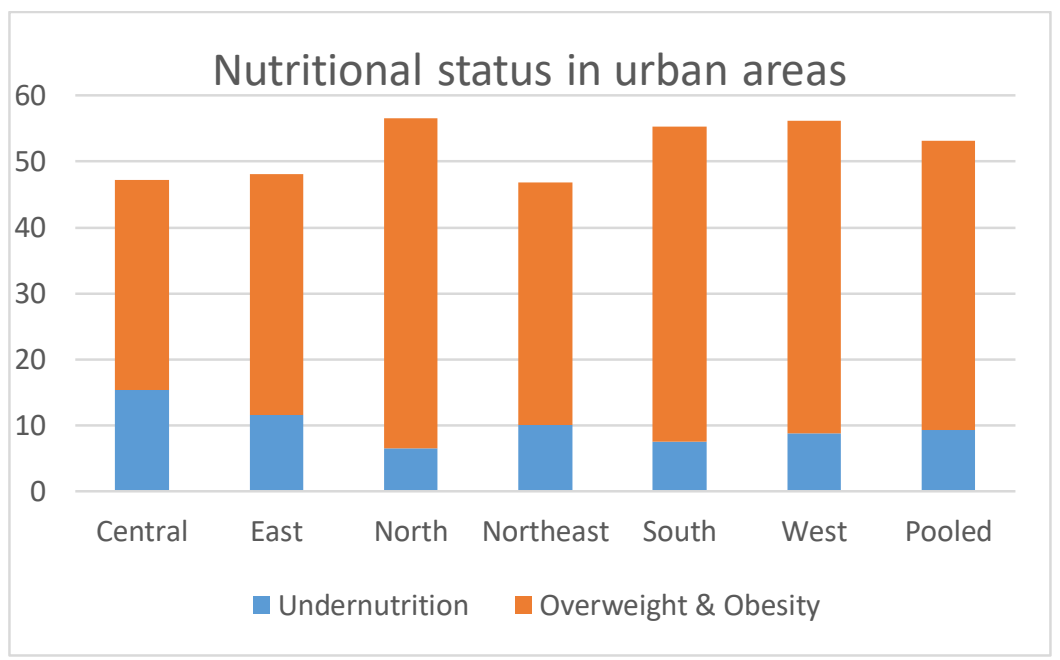

Source: NIN, 2020

Figure 2.2: Nutritional status region-wise - Rural

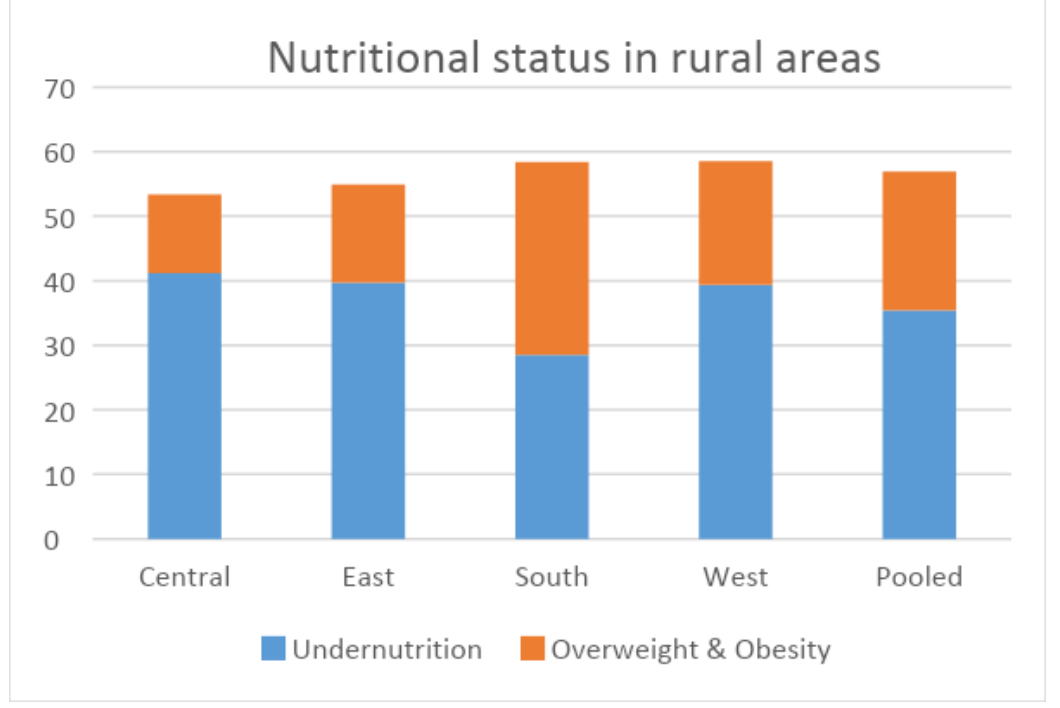

Figure 3.1: Physical activity level state-wise - Male 


\section{Physical Activity (\%) by states - Male}

High-Intensity PA

India

North

Chandigarh

Delhi

Haryana

Himachal Pradesh

Jammu \& Kashmir

Punjab

Rajasthan

Uttarakhand

Central

Chhattisgarh

Madhya Pradesh

Uttar Pradesh

East

Bihar

Jharkhand

Odisha

West Bengal

Northeast

Arunachal Pradesh

Assam

Manipur

Meghalaya

Mizoram

Nagaland

Sikkim

Tripura

West

Dadra \& Nagar Havel

Daman \& Diu

Goa

Gujarat

Maharashtra

South

Andaman \& Nicobar Island

Andhra Pradesh

Karnataka

Kerala

Lakshadweep

Puducherry

Tamil Nadu

Telangana

54.2

Not Working

\begin{tabular}{|l|l|l|l|}
\hline 27.6 & 47.2 & & 25.2 \\
\hline 27.6 & 33.5 & \multicolumn{3}{c}{37.7} & \\
\hline 46.9 & & 27.2 & 25.8 \\
\hline 50.6 & \multicolumn{2}{|c|}{24.2} & 25.1 \\
\hline 47.8 & & 26.9 & 25.2 \\
\hline 56.5 & & 23.1 & 20.3 \\
\hline 55 & & 20.8 & 24.1 \\
\hline 38 & 33.9 & & 28.1 \\
\hline
\end{tabular}

\begin{tabular}{|l|c|c|}
\hline 64.3 & 17.6 & 18 \\
\hline 61 & 20.2 & 18.7 \\
\hline 56.3 & 21 & 22.6 \\
\hline
\end{tabular}

\begin{tabular}{|l|c|c|c|c|}
\hline 51.6 & 20.2 & 28 & \\
\hline 62 & & 18.7 & & 19.2 \\
\hline 54.4 & 21.3 & 24 & \\
\hline 59.5 & 21.9 & & 18.3 \\
\hline
\end{tabular}

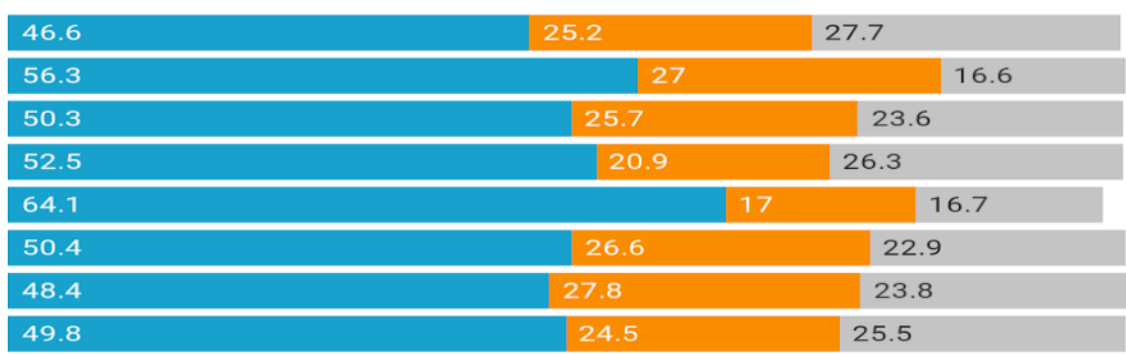

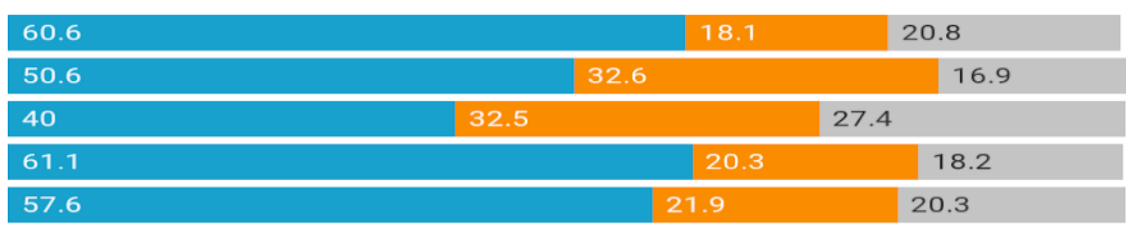

\begin{tabular}{|c|c|c|c|}
\hline 53.8 & & 20.2 & 26 \\
\hline 58.2 & & 23.4 & 18.4 \\
\hline 55.9 & & 24.7 & 19 \\
\hline 41.6 & 33.7 & & 24.6 \\
\hline 41.6 & 32.4 & & 26 \\
\hline 40.8 & 38.3 & & 20.8 \\
\hline 44 & 31.4 & & 24.4 \\
\hline 56.1 & & 23.2 & 20.7 \\
\hline
\end{tabular}


Sanrachana

Figure 3.2: Physical activity level state-wise - female 


\section{Physical Activity (\%) by states - Female}

\begin{tabular}{l|cc|c}
\hline High-Intensity PA & Low-Intensity PA & \multicolumn{2}{c}{ Not Working } \\
India & 21.25 & 8.02 & 69.59
\end{tabular}

North

Chandigarh

Delhi

Haryana

Himachal Pradesh

Jammu \& Kashmir

Punjab

Rajasthan

Uttarakhand

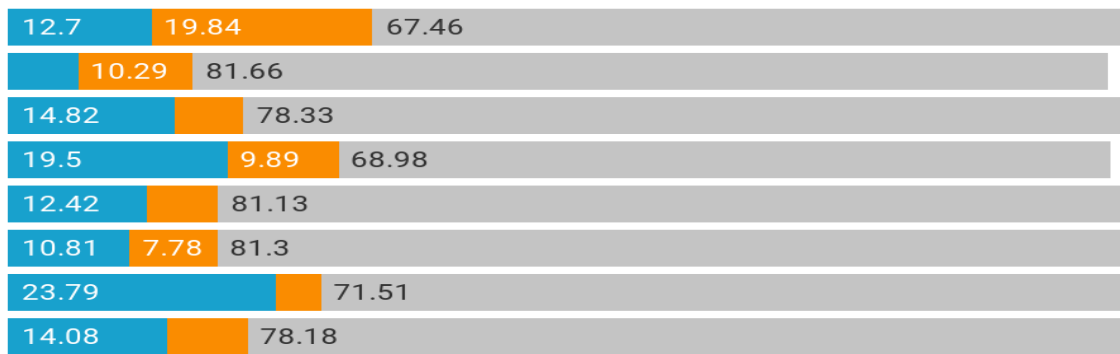

Central

Chhattisgarh

Madhya Pradesh

Uttar Pradesh

\begin{tabular}{|c|c|}
\hline 35.83 & 56.23 \\
\hline 33.5 & 59.52 \\
\hline
\end{tabular}

East

Bihar

Jharkhand

Odisha

West Bengal

\begin{tabular}{|l|c|c|}
\hline 13.53 & 79.5 & \\
\hline 27.5 & \multicolumn{1}{|c|}{66.98} \\
\hline 16.94 & 10.49 & 70.53 \\
\hline 14.81 & \multicolumn{2}{|c|}{76.07} \\
\hline
\end{tabular}

Northeast

Arunachal Pradesh

Assam

Manipur

Meghalaya

Mizoram

Nagaland

Sikkim

Tripura

West

Dadra \& Nagar Haveli

Daman \& Diu

Goa

Gujarat

Maharashtra

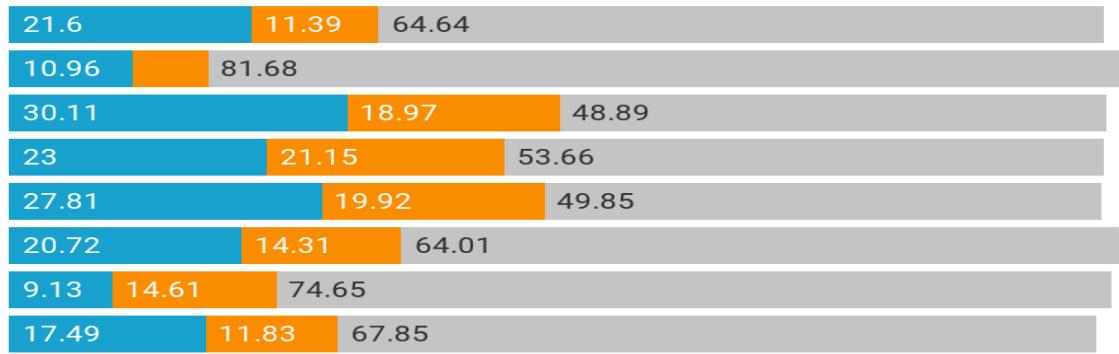

South

Andaman \& Nicobar Island

Andhra Pradesh

Karnataka

Kerala

Lakshadweep

Puducherry

Tamil Nadu

Telangana

\begin{tabular}{|l|l|l|l|l|}
\hline 7.81 & \multicolumn{1}{|c|}{83.08} & & \\
\hline 34.55 & & 9.62 & 55.61 \\
\hline 21.59 & & 9.73 & 67.04 & \\
\hline 8.72 & 12.81 & 78.06 & & \\
\hline 16.9 & 78.87 \\
\hline 9.35 & 11.15 & 78.78 \\
\hline 21.27 & 11.37 & 65.72 & \\
\hline 39.94 & & & \\
\hline
\end{tabular}

Source: NFHS-4 - Created with Datawrapper 
Figure 4.1: Food groups contribution to energy - urban

Contribution of food groups in energy - Urban

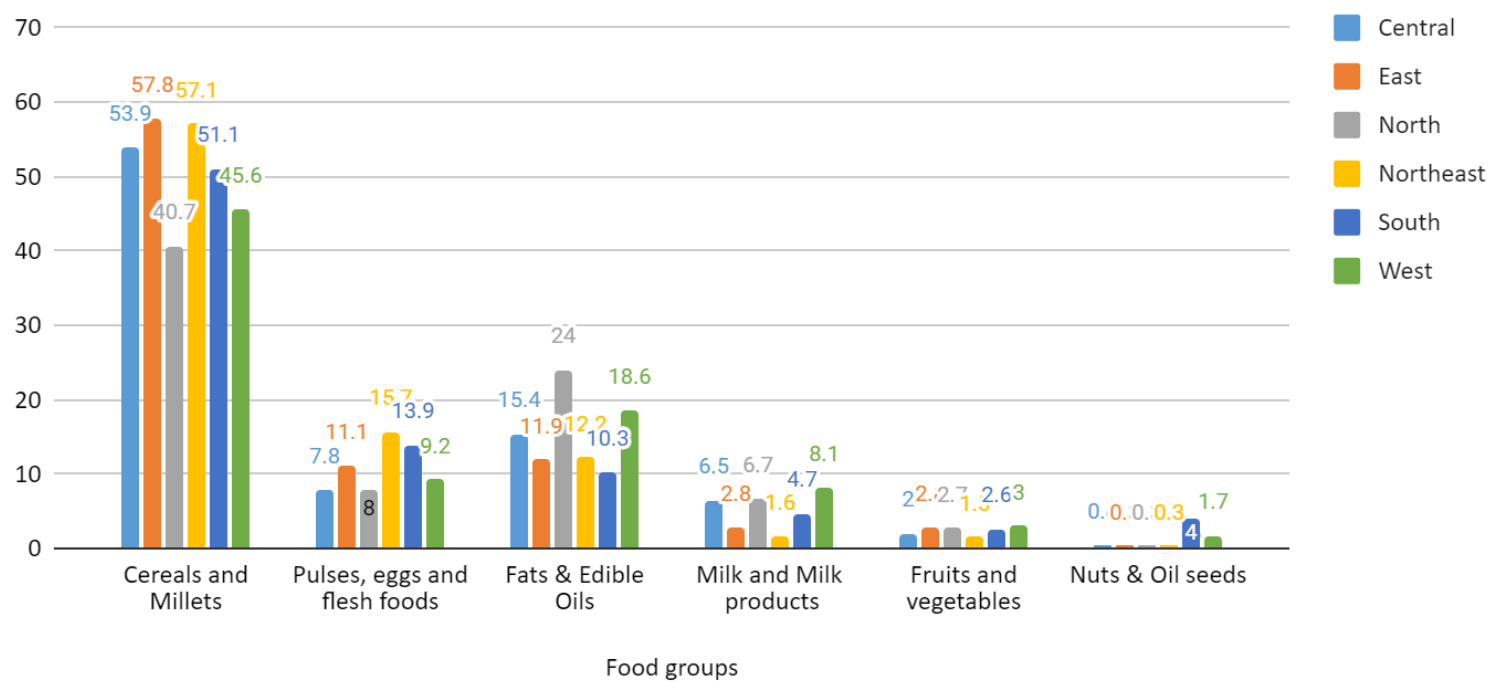

Figure 4.2: Food groups contribution to energy - Rural

Contribution of food groups in energy - Rural

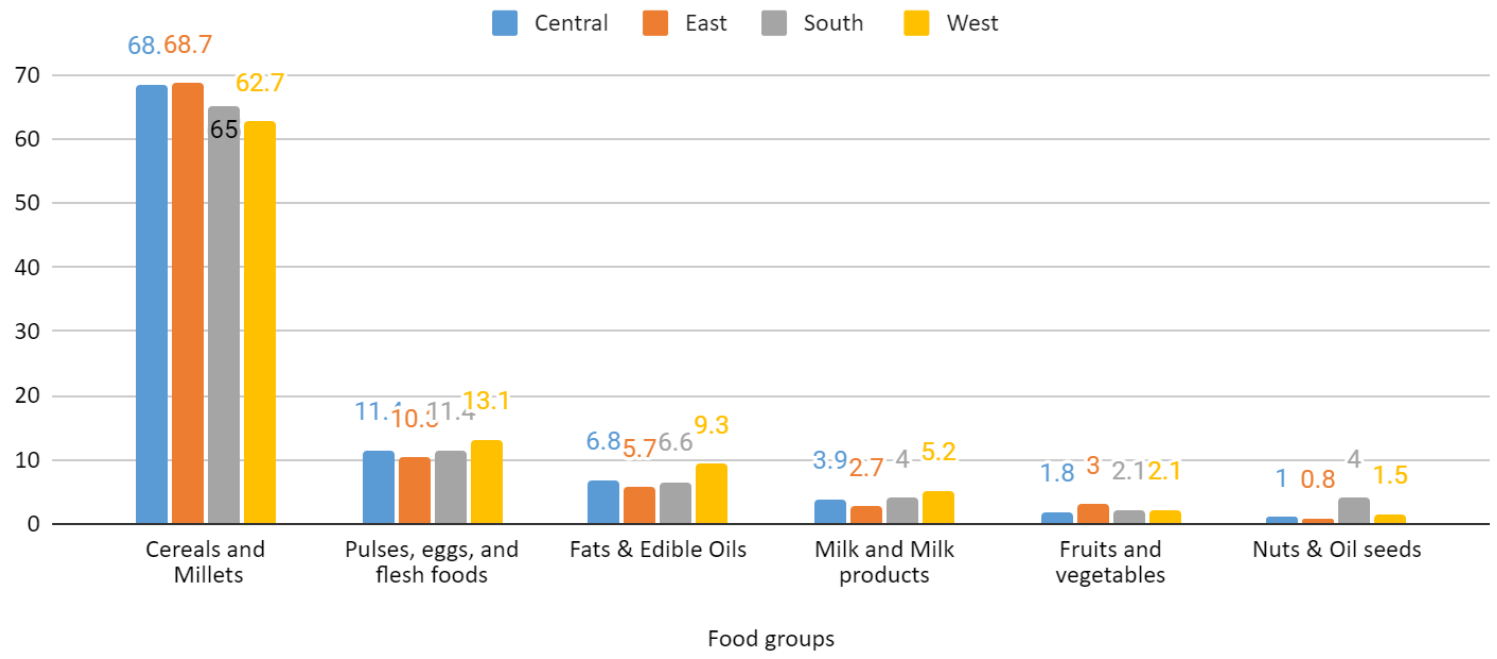

Figure 4.3: Food groups contribution to protein - Urban 


\section{Protein by food groups - Urban}

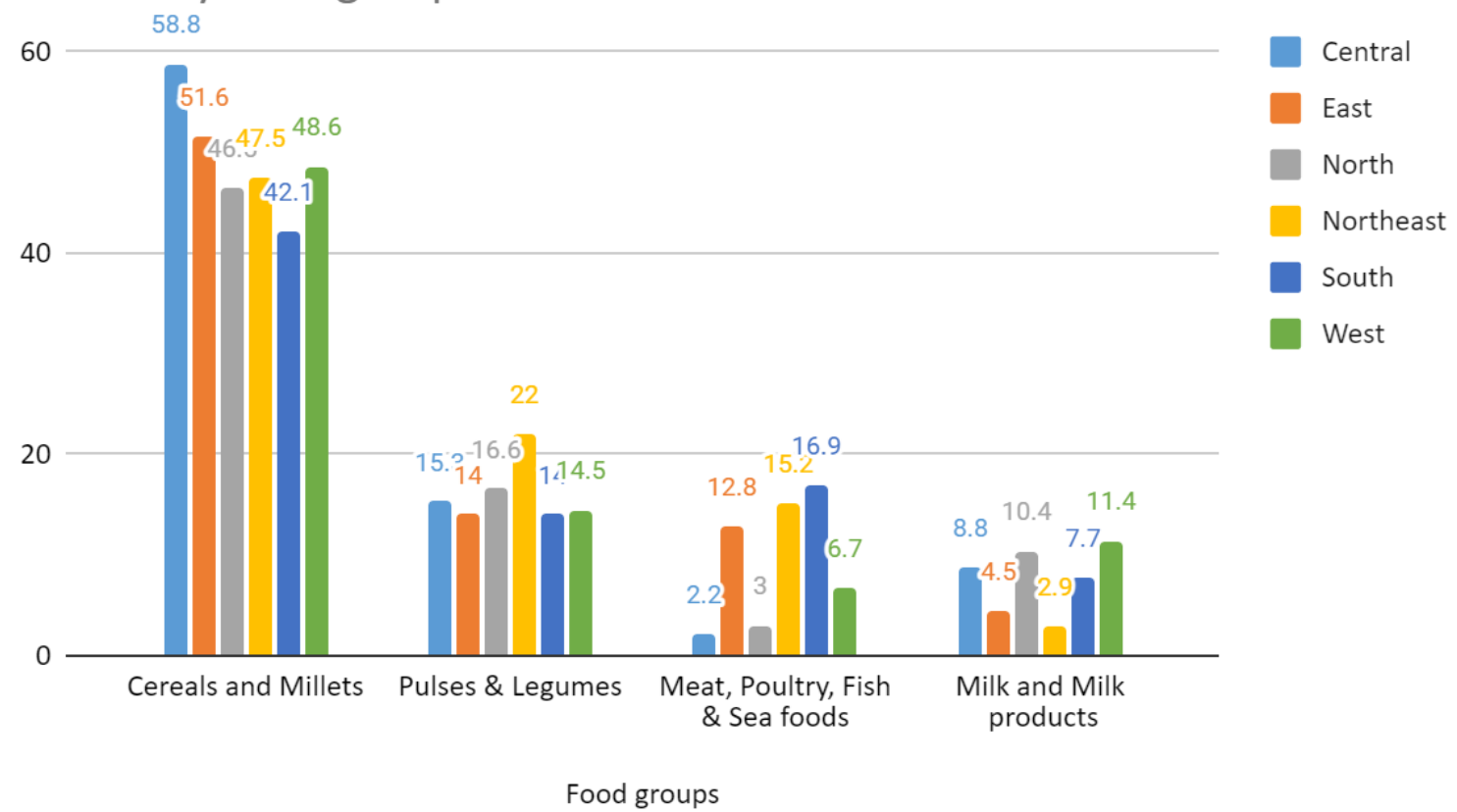

Figure 4.4: Food groups contribution to protein - Rural

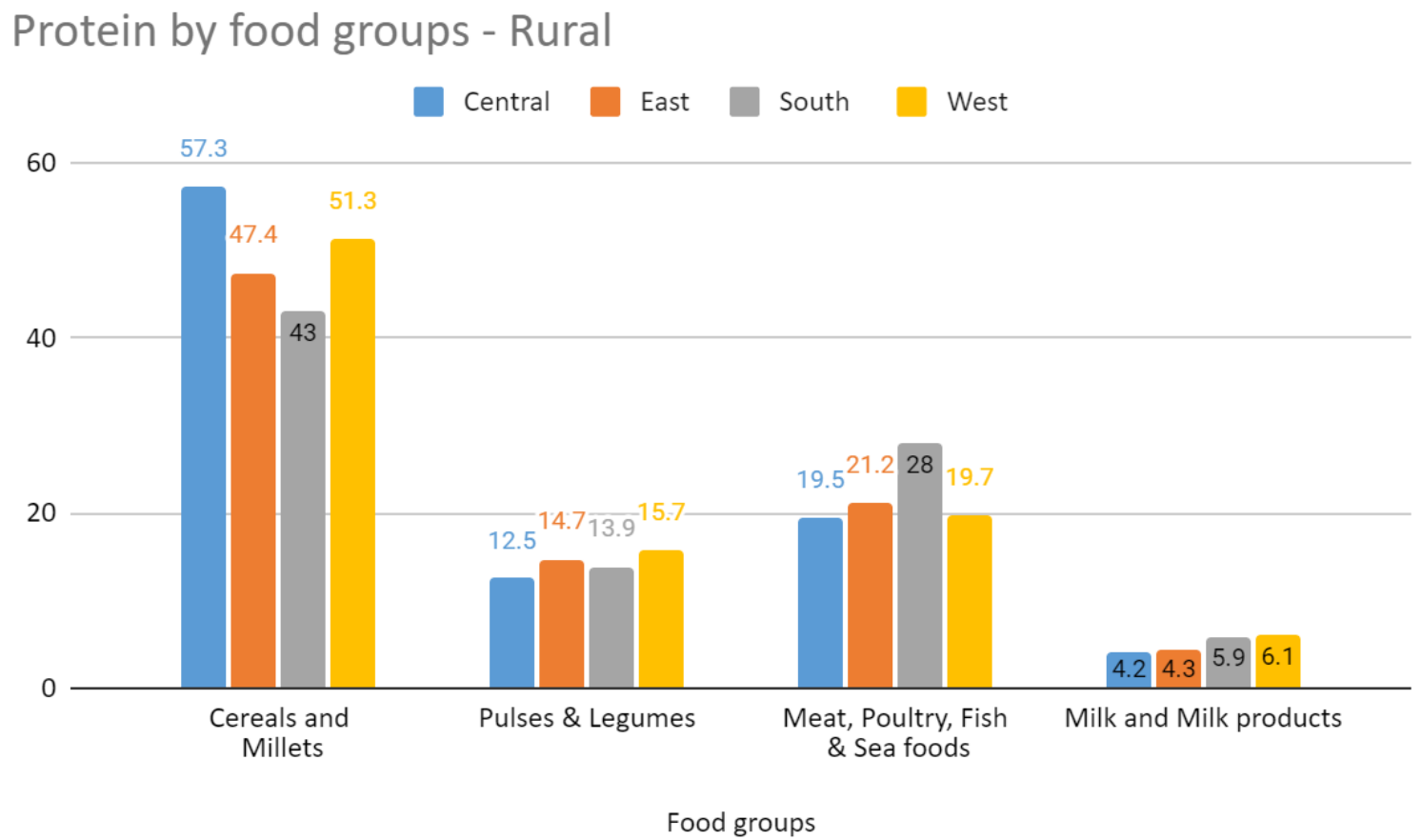

Figure 4.5: Visible and non-visible food source contribution in fat - urban 
Fats from visible and non-visible sources - Urban

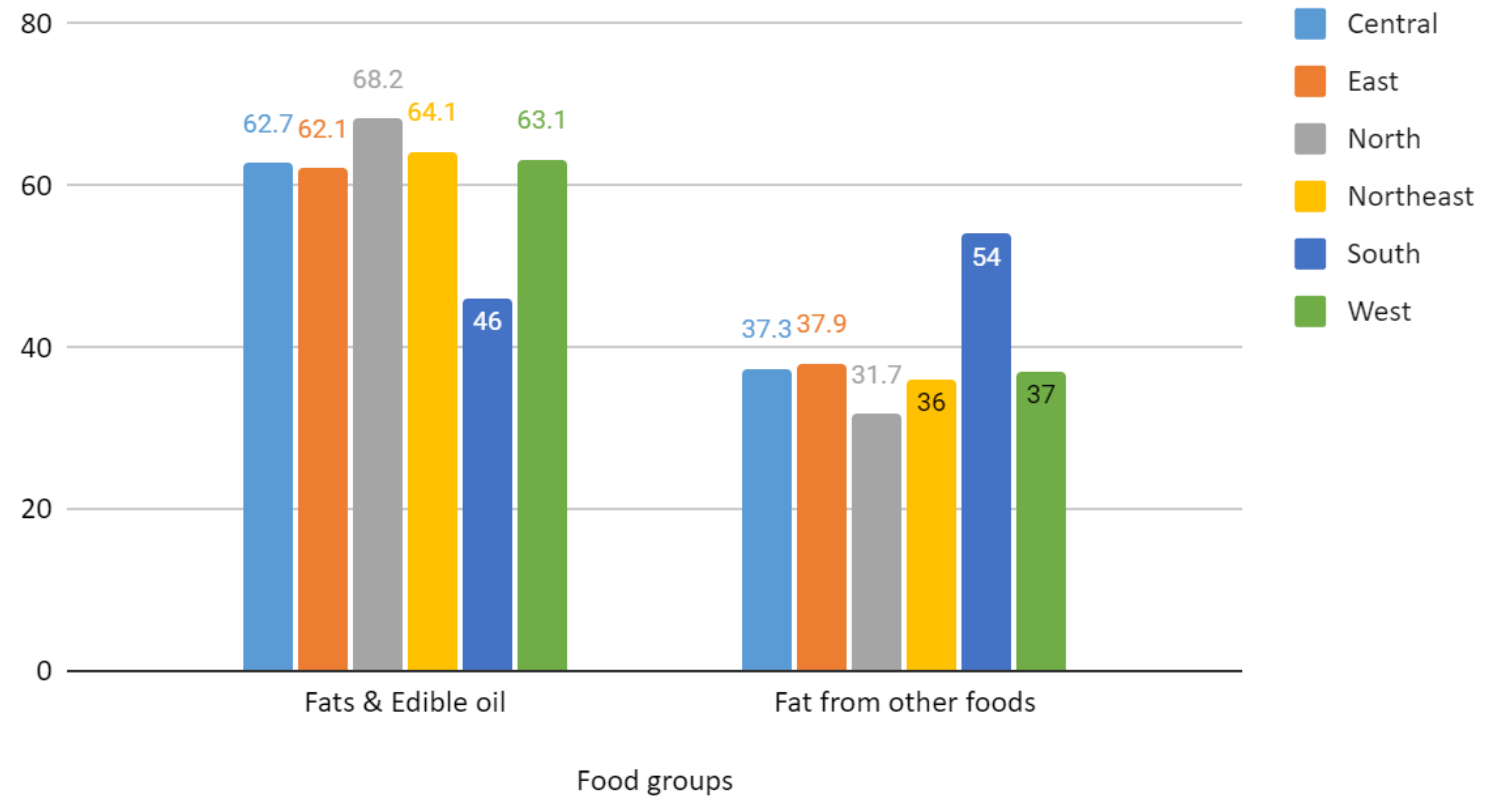

Figure 4.6 Visible and non-visible food source contribution in fat - Rural

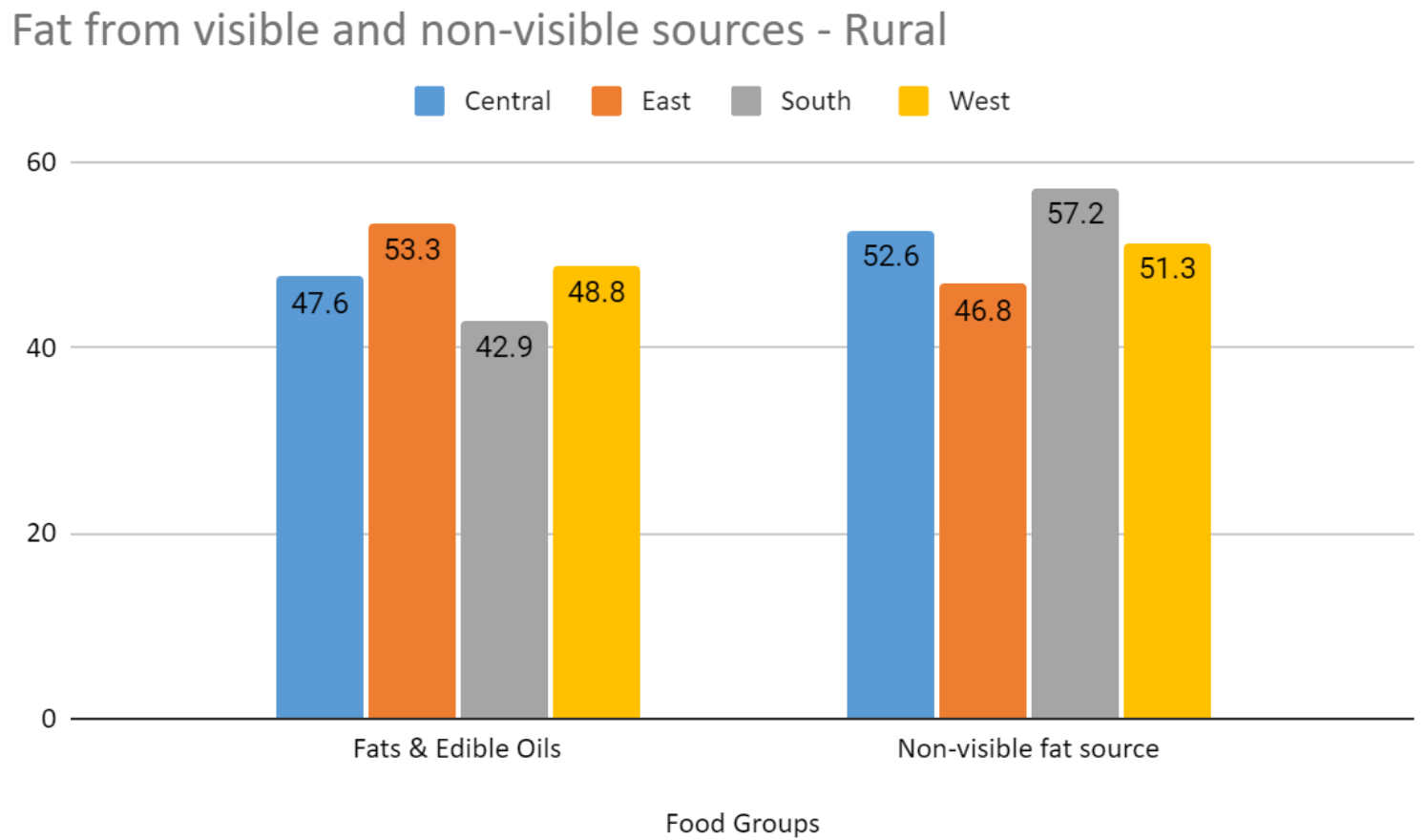

Figure 4.7: Food groups contribution to carbohydrates - Urban 
Carbohydrates from food groups - Urban

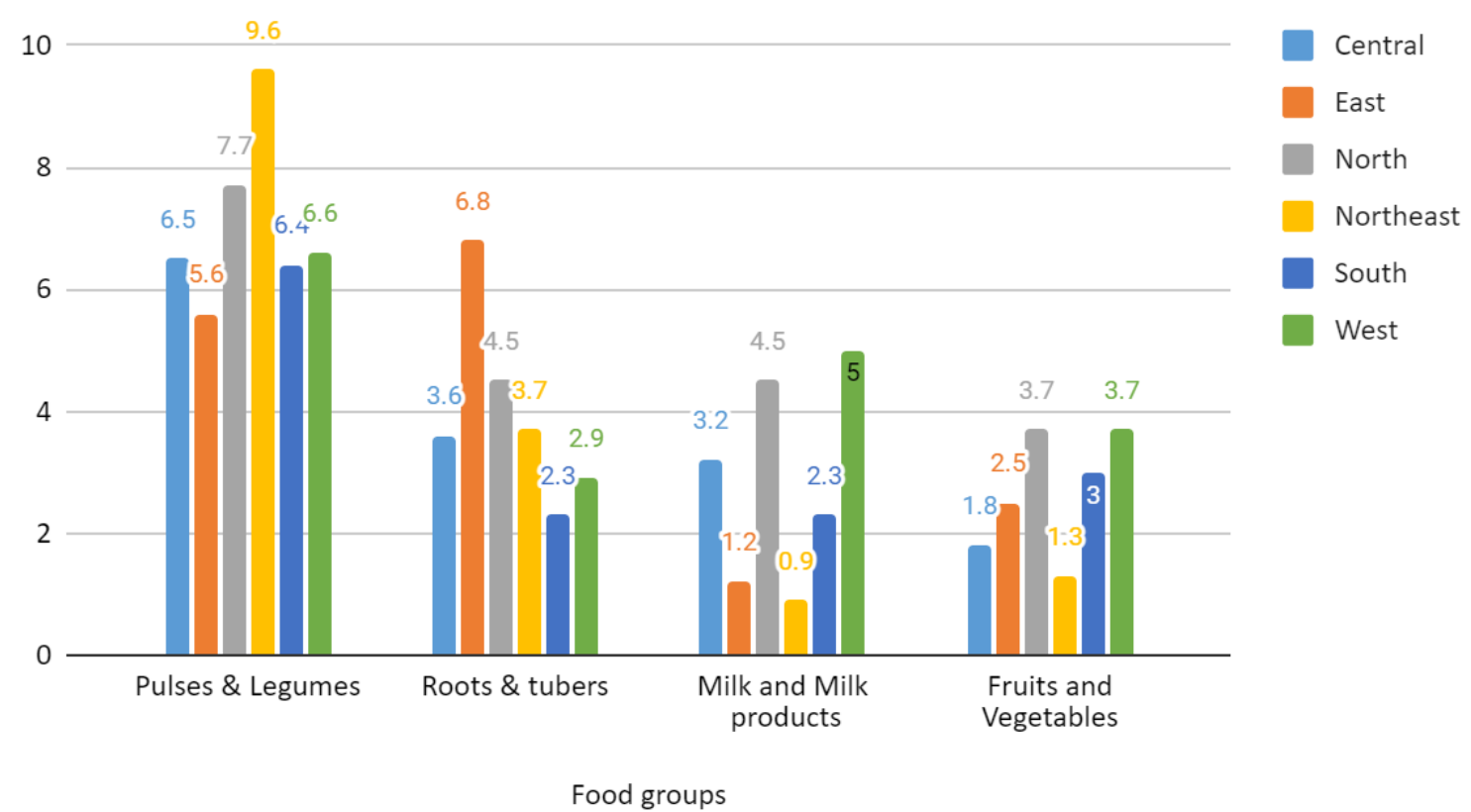

Figure 4.8 Food groups contribution to carbohydrates - Rural

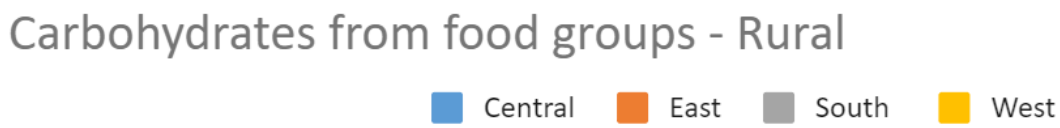

10

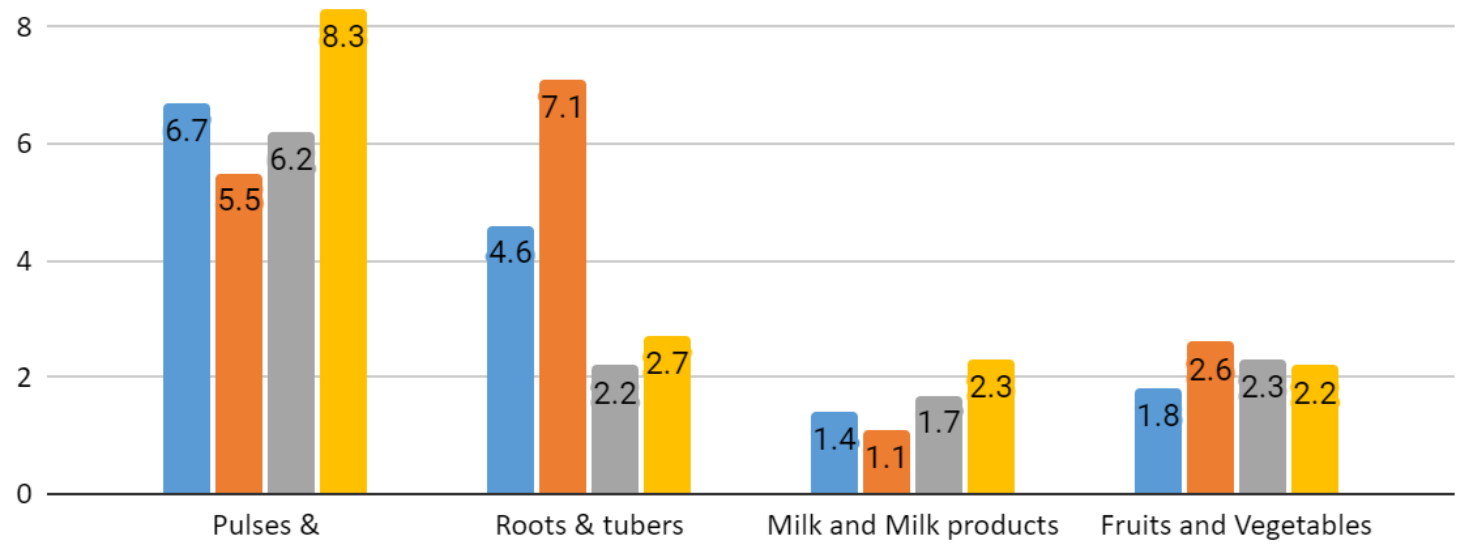

Food groups 